\title{
Proses Pembelajaran Masyarakat Pada Program Konservasi Tanah
}

\author{
Baruna Setyoningrum, Sopingi \\ Jurusan PLS FIP UM, e-mail:baruna_setyoningrum@yahoo.com \\ e-mail: jurusan_pls@fip.um.ac.id
}

\begin{abstract}
Common purpose of this research are to explained public learning process on preparation step of land conservation at DesaJetisLor. And the special purpose of this research are (1)to explain about the public learning process of land conservation social activity program at DesaJetis Lor (2) to know explain public learning process on large school activity of land conservation program at DesaJetisLor (3) to explain about public learning process on RKTD arrangement activity of land conservation at JetisLor.Qualitative approach case study type use in this research.Collecting data method by interview technique, observation and documentation.Analysis technique by data reduction, data display and conclusion.The result of this result show that (1) there is an informal learning process on program socialization process, (2) there is an nonformal learning process on SLKT program, (3) there is an informal learning process on RKTD arrangement process.
\end{abstract}

Keywords: informal learning, nonformal learning, land conservation

\begin{abstract}
Abstrak: Tujuan umum penelitian ini adalah untuk menjelaskan proses pembelajaran masyarakat pada tahap persiapan program konservasi tanah di Desa Jetis Lor. Sedangkan tujuan khusus penelitian ini adalah (1) untuk menjelaskan proses pembelajaran masyarakat pada kegiatan sosialisasi program konservasi tanah di Jetis Lor (2) untuk menjelaskan proses pembelajaran masyarakat pada kegiatan sekolah lapang pada program konservasi tanah di Desa Jetis Lor, (3) untuk menjelaskan proses pembelajaran masyarakat pada kegiatan penyusunan RKTD program konservasi tanah di Jetis Lor. Pendekatan penelitian yang digunakan adalah penelitian kualitatif dengan jenis penelitian studi kasus. Metode pengumpulan data yang digunakan adalah teknik wawancara, observasi dan dokumentasi. Teknik analisa yang digunakan adalah reduksi data, display data, dan penarikan kesimpulan. Hasil penelitian ini menunjukkan bahwa (1) terdapat proses pembelajaran informal di dalam proses sosialisasi program, (2) terdapat proses pembelajaran nonformal di dalam program Sekolah Lapang Konservasi Terpadu (SLKT), (3) terdapat proses pembelajaran informal didalam proses penyusunan Rencana Konservasi Tanah Desa (RKTD).
\end{abstract}

Kata Kunci: pembelajaran informal, pembelajaran nonformal, konservasi tanah

\section{PENDAHULUAN}

Pendidikan merupakan salah satu pilar terpenting dalam meningkatkan kualitas hidup manusia. Pendidikan berfungsi untuk mengembangkan diri bagi pemenuhan kebutuhan hidup, dan memperoleh manfaat dari ilmu pengetahuan dan teknologi, seni dan budaya demi meningkatkan kualitas kehidupan. Untuk itu diperlukan proses yang panjang sepanjang hayat.
Pendidikan dilaksanakan melalui 3 jalur yaitu pendidikan formal, nonformal, dan informal. Hal ini sesuai dengan Undang- undang Republik Indonesia Nomor 20 tahun 2003 tentang Sistem Pendidikan Nasional yang menyebut adanya tiga jalur pendidikan yaitu: pendidikan formal, pendidikan nonformal, dan pendidikan informal (pasal 26, ayat (1). Menurut Zubaedi (2012:135) "pendidikan nonformal diselenggarakan oleh warga masyarakat yang memerlukan 
layanan pendidikan dan berfungsi sebagai pengganti, penambah dan/pelengkap pendidikan formal dalam rangka mendukung pendidikan sepanjang hayat". Menurut Kamil (2009:13) menyebutkan definisi pendidikan informal adalah "sebuah proses pendidikan yang tidak terorganisir dan seringkali tidak sistematis; namun demikian pendidikan informal berperan besar dalam pembelajaran sepanjang hayat semua orang, termasuk orang yang berpendidikan tinggi sekalipun. Dengan kata lain, pendidikan informal memiliki kaitan yang sangat erat dengan pembelajaran pengalaman”.

Rogers dalam Kamil (2009:12) menyebutkan bahwa "pendidikan informal dimaknai sebagai suatu proses pendidikan sepanjang hayat dimana setiap individu memperoleh dan mempelajari tingkah laku, norma-norma, keterampilan, pengetahuan dari pengalaman seharisehari, dan pengaruh serta sumber-sumber pendidikan di lingkungan sekitarnya; dari keluarga, tetangga, lingkungan kerja dan lingkungan bermain, tempat belanja, dan perpustakaan serta media massa".

Definisi yang diberikan oleh Rogers menunjukkan bahwa pendidikan informal merupakan proses pendidikan yang terjadi dalam kehidupan sehari-hari, yang proses pelaksanaannya tidak didesain secara sengaja sebagai kegiatan pembelajaran (not by design), karena terintegrasi dengan aktivitas-aktivitas lain yang dari kegiatan tersebut seseorang dapat belajar dan/atau memperoleh pengetahuan, keterampilan atau perubahan sikap yang lebih baik.

Program konservasi tanah di Desa

Jetis Lor, Kecamatan Nawangan Kabupaten Pacitan merupakan program pemberdayaan masyarakat yang berkaitan dengan upaya-upaya yang dilakukan oleh masyarakat Jetis Lor dan difasilitasi oleh LPTP Solo untuk mengatasi masalah kegersangan dan kekeringan tanah lereng bukit akibat penggundulan hutan. Program konservasi tersebut juga dilakukan untuk mengatasi terjadinya erosi tanah. Program konservasi tersebut juga dilakukan untuk mengatasi terjadinya erosi tanah dan pengurangan peggunaan kayu yang juga menjadi penyebab utama hutan gundul dan eroosi tanah.

Secara teknis, program konservasi tanah merupakan bidang pertanian dan/atau perhutanan, di mana proses untuk menghijaukan kembali tanah atau upaya reboisasi lahan dilakukan berdasarkan prinsip-prinsip atau teori pengelolaan lahan pertanian. Namun dalam implementasinya, pelaksanaan program itu sarat dengan proses-proses pembelajaran masayarakat, terutama pada tahap persiapan program. Proses-proses pembelajaran dimaksud terutama pembelajaran secara nonformal dan informal.

Berdasarkan hasil studi atau penelitian pendahuluan diperoleh data bahwa program konservasi tanah di Jetis Lor dilaksanakan dengan menggunakan pendekatan pembelajaran bagi masyarakat, terutama pada tahap persiapan. Artinya program konservasi lahan yang orientasi untuk mengatasi kekeringan dan erosi lahan dilakukan dengan prinsi-prinsip pembelajaran, terutama pembelajaran informal maupun nonformal.

Penelitian ini dilakukan dengan maksud untuk mengungkap dan mendeskripsikan tentang berbagai proses pembelajaran bagi masyarakat yang dilakukan pada program konservasi tanah di Desa Jetis Lor Kecamatan Nawangan Kabupaten Pacitan. Penelitian ini penting dilakukan karena beberapa alasan. 
Pertama, belum banyak penelitian yang mengungkap tentang pembelajaran informal yang ada di masyarakat, padahal porsi terbesar proses belajar yang terjadi di masyarakat adalah pembelajaran melalui jalur informal. Dengan kajian ini diharapkan dapat menambah khazanah ragam pembelajaran informal yang terjadi di masyarakat yang dapat diungkap. Kedua, keberhasilan program konservasi tanah di desa Jetis Lor tidak dapat dilepaskan dari kegiatan pembelajaran. Bahwa program konservasi tanah tersebut merupakan program pemberdayaan masyarakat yang dijalankan dengan prinsip-prinsip pendidikan, terutama pendidikan informal. Hal demikian perlu diungkap untuk menunjukkan bahwa pendidikan informal, sebagai bagian dari kajian pendidikan luar sekolah, memiliki peran penting dalam pemberdayaan masyarakat.

Pelaksanaan program konservasi tanah di Desa Jetis Lor sarat dengan proses-proses pembelajaran masyarakat. Mengingat cakupan program konservasi tersebut sangat luas, maka fokus penelitian ini dibatasi pada tahap persiapan program. Artinya yang menjadi fokus penelitian ini adalah proses pembelajaran masyarakat pada tahap persiapan program konservasi tanah di Jetis Lor. Pemilihan batasan fokus penelitian tersebut didasarkan pertimbangan berikut. Program konservasi tanah di Jetis Lor dilaksanakan mulai tahun 2003, dan sampai sekarang (2014) masih berjalan dan berhasil. Kelompokkelompok petani konservasi (KPK) yang dibentuk sebagai wadah untuk mengorganisasikan kegiatan konservasi pada tahun 2003, sampai saat ini juga masih fungsional.

Kondisi demikian terjadi karena proses tahap persiapan dilakukan secara matang, artinya tahap persiapan menjadi tahap penting yang sangat menentukan keberhasilam dan keberlanjutan program. Program konservasi tanah di Jetis Lor yang hingga saat ini sudah berjalan lebih dari 10 tahun, merupakan bukti bahwa program itu masih berjalan dan berlanjut.

Tujuan penelitian ini adalah untuk mendeskripsikan proses pembelajaran masyarakat pada tahap persiapan program konservasi tanah di Desa Jetis Lor. Sekurang-kurangnya terdapat 3 kegiatan yang sarat dengan pembelajan masyarakat pada tahap persiapan program tersebut, yaitu; a) kegiatan sosialisasi, b) kegiatan sekolah lapang konservasi terpadu (SLKT), dan c) kegiatan penyusunan Rencana Konservasi Tanah Desa (RKTD). Oleh karena itu, tujuan khusus penelitian ini adalah untuk mendeskripsikan prosesproses pembelajaran masyarakat pada kegiatan sosialisasi program konservasi tanah di Jetis Lor, untuk mendeskripsikan proses-proses pembelajaran masyarakat pada kegiatan Sekolah Lapang Konservasi Terpadu (SLKT) pada program konservasi tanah di Jetis Lor, untuk mendeskripsikan proses-proses pembelajaran masyarakat pada kegiatan penyusunan RKTD program konservasi tanah di Jetis Lor.

Proses pembelajaran masyarakat pada penelitian ini adalah kegiatan pembelajaran baik nonformal maupun informal yang dilakukan atau dialami masyarakat Jetis Lor yang berkaitan dengan tahap persiapan program konservasi tanah di desa Jetis Lor. Prosesproses pembelajaran masyarakat yang berkaitan dengan program konservasi tersebut terjadi pada (a) kegiatan sosialisasi program, (b) kegiatan sekolah lapang konservasi terpadu(SLKT), dan (c) kegiatan penyusunan rencana konservasi tanah desa (RKTD). 
Dari proses pembelajaran yang ada didalam tahap persiapan program ini, banyak manfaat yang didapat oleh masyarakat. Masyarakat memperoleh berbagai ilmu pengetahuan yang dibawa oleh LPTP dan mereka juga dapat mengembangkan pengetahuan yang sudah dimiliki untuk menjadi lebih baik. Mereka dapat mengidentifikasi masalah sendiri, dapat menyelesaikannya masalah sendiri. Karena pada tahap ini mereka juga diajarkan tentang berbagai macam erosi dan longsor yang terjadi pada lahan, mereka dapat melakukan kegiatan pengkonservasian dengan baik, mereka juga paham bagaimana cara pengolahan lahan, pembibitan.

\section{METODE}

Lokasi penelitian yaitu di desa Jetis Lor kecamatan Nawangan Kabupaten Pacitan. Dengan fokus pada proses pembelajaran masyarakat pada tahap persiapan program konservasi tanah di Jetis Lor. Pendekatan yang dilakukan penelitian ini adalah penelitian kualitatif dengan jenis penelitian studi kasus yang dimaksudkan untuk mengungkap prosesproses pembelajaran masyarakat pada tahap persiapan program konservasi tanah di Jetis Lor. Penelitian ini menggunakan penelitian kualitatif untuk mengungkapkan proses pembelajaran masyarakat yang terjadi dalam program konservasi dengan penggalian data secara mendalam dari informan yang terpercaya dan telah dipilih. Menurut Moedzakir (2010:1) "penelitian kualitatif adalah sebuah pendekatan penelitian yang diselenggarakan dalam setting alamiah, memerankan peneliti sebagai instrumen pengumpul data, menggunakan analisis induktif, dan berfokus pada makna menurut perspektif partisipan."
Data yang digali dalam penelitian ini adalah proses-proses pembelajaran masyarakat dari tahap persiapan program konservasi tanah di Jetis Lor, dan dengan sumber data yaitu warga masyarakat Jetis Lor yang terlibat aktif pada proses kegiatan persiapan program dan tim fasilitator yang melakukan fasilitasi persiapan program. Oleh karena itu, pengumpulan data pada penelitian ini dilakukan melalui wawancara mendalam kepada sumber data tersebut. Sumber data yang lain berupa dokumen tertulis yang terkait dengan proses pelaksanaan tahap persiapan program. Oleh karena itu maka pengumpulan data juga dilakukan melalui studi dokumen.

Data diperoleh berdasarkan wawancara kepada informan yang berperan langsung dalam pelaksanaan program konservasi tanah dengan aktif. Dalam penelitian ini yang pertama dilakukan adalah melakukan wawancara tentang proses pembelajaran pada tahap persiapan yaitu sosialisasi program, SLKT dan penyusunan RKTD.

Sumber data dalam penelitian adalah; a) warga Jetis Lor yang terlibat aktif dalam kegiatan tahap persiapan program konservasi tanah yaitu pak Kaspani, pak Soman, pak Komar dan tim fasilitator dari LPTP Solo yang melakukan proses fasilitasi persiapan program; b) dokumen tertulis yang terkait dengan proses pelaksanaan tahap persiapan program yaitu dokumen RKTD, panduan konservasi tanah tertulis yang terkait dengan penyelenggaraan sekolah lapang tersebut. Analisis data yang digunakan adalah analisis data interaktif yang meliputi kegiatan mereduksi data, mendisplay data, dan verifikasi. Sedangkan uji keabsahan temuannya 
dilakukan dengan teknik triangulasi teknik dan sumber (Sugiyono, 2010:97).

\section{HASIL}

Sebelum suatu program itu terlaksana, dilakukan persiapan-persiapan untuk keberhasilan program yang akan dilaksanakan. Tahap persiapan yang dilakukan dalam kegiatan konservasi ini adalah tahap sosialisasi konservasi, tahap proses sekolah lapang, dan tahap penyusunan sekolah lapang. Hal ini dilakukan agar masyarakat yang belum mengetahui tentang program tersebut menjadi mengerti tujuan program itu dilaksanakan. Dari proses sosialisasi ini pula program yang akan dijalankan menentukan akan berjalan terus atau berhenti begitu saja. Maka proses sosialisasi ini harus dikemas dengan baik agar masyarakat yang mengikuti kegiatan ini tidak merasa bosan. Jika masyarakat mulai bosan dengan proses ini maka, dari pihak pemilik program harus pintar untuk menindak lanjuti hal ini.

Sosialisasi yang akan disampaikan kepada masyarakat haruslah tidak membosankan. Karena proses sosialisasi merupakan komponen penting sebelum program pemberdayaan dilaksanakan. Kegiatan sosialisasi ini tidak hanya dilakukan di desa saja namun dilakukan juga di tiap dusun. Ini dilakukan agar kegiatan sosialisasi dapat menjangkau semua warga masyarakat dan dapat lebih khusus mengidentifikasi masalah yang ada. Selain sosialisasi yang diadakan di desa tepatnya dibalai desa dan di setiap dusun tepatnya dimasing-masing rumah kepala dusun, LPTP juga melakukan sosialisasi dari rumah kerumah. Mereka melakukan wawancara mendalam saat datang kerumah-rumah. Wawancara yang dimaksud tentu saja tidak yang formal tapi mereka seperti bersilaturahmi kerumah warga tersebut. Ada kegiatan yang dilakukan dalam sosialisasi program konservasi sehingga masyarakat maupun LPTP dapat belajar dari hal yang dilakukan salah satunya adalah kegiatan tentang penyadaran yang dilakukan LPTP bahwa tanah mereka telah terkikis erosi. Kegiatan itu merupakan kegiatan yang dilakukan dilapangan atau lahan milik masyarakat. Mereka disana melakukan identifikasi masalah apa yang selama ini terjadi pada lahan mereka.

Kegiatan sosialisasi yang digunakan LPTP banyak didalamnya terdapat pendidikan informal. Hal ini dapat dilihat dari LPTP melakukan berbagai penyadaran agar masyarakat itu tahu dan mengerti bahwa mereka sebenarnya mampu hanya saja mereka juga harus banyak belajar. Kegiatan sosialisasi yang dilakukan LPTP ini tidak hanya dilakukan didalam forum diskusi yang jadwalnya telah ditetapkan. Kegiatan ini juga terjadi ditempat para petani biasanya bekerja. Melakukan pemetaan lahan dan dari sana mereka dapat belajar banyak bagaimana mengidentifikasi masalah dan memecahkan permasalahan itu. Dari kegiatan sosialisasi ini masyarakat sudah mendapatkan banyak pengetahuan baru yang dapat dikembangkan sampai saat ini

Masyarakat yang mengikuti kegiatan konservasi secara otomatis juga mengikuti kegiatan sekolah lapang. Ada beberapa tahapan teknis yang harus dilakukan masyarakat terkait dengan konsservasi. Seperti membuat terasering, SPA, BTA, teras bangku. Seluruh kegiatan teknis ini dilakukan ketika masyarakat sudah mendapatkan materi-materi yang diajarkan LPTP di sekolah lapang. Karenadisekolah lapang berbagai teknis tentang konservasi dipersiapkan untuk 
masyarakat. Pengetahuan yang sudah didapatkan masyarakat dari LPTP diterapkan langsung kelapangan. Kurikulum yang diterapkan didalamSLKT adalah kurikulum yang disepakati bersama antara LPTP dan masyarakat. LPTP membawa pengetahuan baru terkait dengan konservasi lalu dimasukkan ke dalam kurikulum dan juga mengikuti kebutuhan yang dibutuhkan oleh masyarakat. Jadi kurikulum yang diterapkan didalam sekolah lapang tidak murni dari salah satu pihak, tapi ide dari LPTP dan juga masyarakat.

Segala kegiatan yang dilakukan oleh masyarakat desa Jetis Lor terpatok pada apa yang telah dilakukan nenek moyang dahulu terhadap pertanian. Tetapi seiring berkembangnya zaman, mereka mulai mempelajari ilmu-ilmu tentang pertanian. Terlebih lagi ada LPTP yang masuk dan membawa program konservasi tanah ini. Segala hal yang terkait dengan konservasi dimasukkan kedalam sekolah lapang. Hal ini tentu saja berbeda dengan apa yang dilakukan LPTP dan nenek moyang mereka terkait dengan pengolahan tanah. Peran sekolah lapang dalam kegiatan konservasi sangat penting. Karena didalam sekolah lapang pengetahuan-pengetahuan baru itu diajarkan.

Pada proses pembelajaran sekolah lapang banyak hal yang dipelajari. Masyarakat yang mengikuti kegiatan konservasi secara otomatis juga mengikuti kegiatan sekolah lapang.Ada beberapa tahapan teknis yang harus dilakukan masyarakat terkait dengan konsservasi. Seperti membuat terasering, SPA, BTA, teras bangku. Tapi di dalam sekolah lapang bukan hanya pengetahuan baru yang dibawa dari LPTP tapi juga pengetahuan yang dimiliki masyarakat untuk lebih dipoeles didalam sekolah lapang. Seluruh kegiatan teknis ini dilakukan ketika masyarakat sudah mendapatkan materi-materi yang diajarkan LPTP di sekolah lapang. Karenadisekolah lapang berbagai teknis tentang konservasi dipersiapkan untuk masyarakat. Pengetahuan yang sudah didapatkan masyarakat dari LPTP diterapkan langsung kelapangan.

Kurikulum yang diterapkan didalam SLKT adalah kurikulum yang disepakati bersama antara LPTP dan masyarakat. LPTP membawa pengetahuan baru terkait dengan konservasi lalu dimasukkan ke dalam kurikulum dan juga mengikuti kebutuhan yang dibutuhkan oleh masyarakat. Jadi kurikulum yang diterapkan didalam sekolah lapang tidak murni dari salah satu pihak, tapi ide dari LPTP dan juga masyarakat. Strategi sekolah lapang dalam kegiatan konservasi ini sangat bagus. Disini LPTP menerapkan system kurikulum yang tidak kaku. Berbagai pelatihan-pelatihan diajarkan disekolah lapang ini.

Waktu yang ditentukan pun sangat fleksibel ditentukan oleh masyarakat sendiri dan kesepakatan antara LPTP. Hal ini dilakukan karena masyarakat desa Jetis Lor sebagian besar bermata pencaharian sebagai petani yang bekerja pada pagi hari dan pulang sore hari. Mereka juga tidak mau jika tidak pergi kesawah. Untuk itu LPTP menerapkan system kurikulum yang fleksibel dalam penerapan sekolah lapang.

Suatu desa harus memiliki perencanaan-perencanaan jangka panjang untuk menjadikan desa itu lebih baik lagi. Didalam penyusunan RKTD ini LPTP ini melibatkan masyarakat juga. Karena masyarakat yang paling tahu tentang keadaaan desa mereka. Penyusunan RKTD ini dilakukan oleh masyarakat dan LPTP 
sebagai pendamping. Penyusunan RKTD dilakukan masyarakat dengan LPTP. LPTP yang memiliki ide lalu memberi pemahaman kepada masyarakat. Didalam penyusunan ini ada diskusi yang terjadi antara LPTP dengan masyarakat.

Banyak hal yang dilakukan ketika akan menyusun RKTD. Yang terpenting adalah melakukan pendataan terhadap lahan-lahan yang ada di setiap dusun. Banyak komponen yang harus didata terkait dengan penyusunan RKTD tersebut. Dalam penyusunan RKTD ini masyarakat juga belajar tentang jenis-jenis erosi, jenis-jenis tanah yang diajarkan LPTP ketika melakukan penelusuran lapangan. Ada proses-proses pembelajaran didalam penyusunan RKTD ini. Masyarakat banyak belajar tentang pengetahuan-pengetahuan baru dari LPTP begitupun LPTP juga banyak belajar tentang pandangan masyarakat tentang lahan dari capaian pengetahuan masyarakat.

Pada tahap persiapan program konservasi ada proses pembelajaran yang dilakukan didalamnya. Pada tahap sosialisasi ada proses pembelajaran informal, pada sekolah lapang ada proses pembelajaran nonformal dan pada penyusunan RKTD ada proses pembelajaran informal. Dari tahap persiapan ini dapat dilihat keberlanjutan program mulai dari pelaksanaan hingga saat ini.

\section{PEMBAHASAN}

Dalam kegiatan program pemberdayaan salah satu komponen penting adalah kegiatan sosialisasi. Adanya sosialisasi ini dapat menstimulus terjadinya interaksi antara pemilik program dan juga masyarakat sasaran. Asumsi tersebut dikuatkan oleh Gillin dalam Soekanto (2009:55) "bahwa interaksi sosial merupakan syarat utama terjadinya aktivitas-aktivitas sosial. Interaksi sosial merupakan hubunganhubungan sosial yang dinamais yang menyangkut hubungan antara orang-orangperorangan, antara kelompok-kelompok manusia maupun antara perorangan dengan kelompok manusia”.

Dalam hal ini pemilik program adalah LPTP. Yangmana LPTP mempunyai tugas penting untuk dapat memberikan pemahaman kepada masyarakat desa Jetis Lor terkait dengan program konservasi yang akan dilaksanakan melalui sosialisasi program. Segala bentuk sosialisasi yang dilakukan LPTP di Desa Jetis Lor bisa dikatakan berhasil apabila masyarakat menerima program konservasi ini dengan senang hati dan tangan terbuka. Interaksi yang terjadi di dalam proses sosialisasi ini, ingeraksi antara LPTP dan masyarakat berjalan cukup lancar dan masyarakat sangat senang dengan hadirnya LPTP.

Segala bentuk sosialisasi yang dilakukan LPTP di Desa Jetis Lor bisa dikatakan berhasil. Masyarakat menerima program konservasi ini dengan senang hati dan tangan terbuka. Dengan adanya kegiatan sosialisasi ini proses pembelajaran sudah terjadi didalamnya. Masyarakat banyak menerima informasi baru dari LPTP dari kegiatan sosialisasi ini. Asumsi ini diperkuat oleh Lovell dalam Baslemen dan Mappa mengemukakan bahwa "sebagian besar bahan yang dipelajari oleh orang dewasa, baik yang dipelajari dalam lingkup pendidikan sekolah dan luar sekolah maupun sebagai akibat dari belajar secara kebetulan (insidental) sebagai konsejuensi yang tak dapat dielakkan dari kegiatan rutin sehari-hari, diperoleh peserta belajar 
dalam bentuk verbal ketikan bertemu dengan fasilitator, membaca buku atau makalah, mendengarkan radio atau menonton televisi, mempelajari buku pedoman dan mendisikusikan sesuatu dengan teman, kesemuanya merupakan upaya memperoleh informasi".

Kegiatan sosialisasi masyarakat banyak belajar dari LPTP secara tidak langsung. Maksudnya adalah dalam kegaitan penelusuran dilapangan proses belajar itu sebenarnya berlangsung. Cara memecahkan masalah itu mereka dapatkan di penelusuran lahan itu. LPTP memiliki tugas mengarahkan masyarakatmasyarakat. Dalam proses pembelajaran ini ditemukan bahwa didalam kegiatan sosialisasi ditemukan tentang pembelajaran informal. Asumsi ini diperkuat oleh Supriyono (2012:23) yaitu "Pada kuadran C menggambarkan varian pendidikan informal tipe 1 dimana ada kesengajaan dari pihak pendidik (sumber belajar) untuk membantu atau mengarahkan peserta didik tertentu guna memperoleh pengalaman belajar, sedangkan pihak peserta didik tidak sengaja untuk belajar sesuatu dengan bantuan pendidik. Kegiatan belajar semacam ini termasuk dalam kategori pendidikan informal tipe 1 . Pendidikan informal tipe ini dapat berbentuk perorangan, kolektif dan massal, yaitu pendidikan informal secara kolektif yaitu melalui kegiatan-kegiatan kelompok yang memiliki kepentingan bersama. Pendidikan informal secara kolektif ini merupakan bentuk pemberdayaan masyarakat yang terselenggara karena diciptakan oleh pemerintah atau agensi pendidikan masyarakat secara mandiri( pendidik semi profesional)".

Proses pembelajaran informal ini tidak hanya terlihat dalam sosialisasi penelusuran lahan antara masyarakat dan LPTP. Pemberlajaran ini juga terlihat ketika LPTP melakukan sosialisasi tungku dan melalui pendekatan dari rumah ke rumah. Pendekatan dilakukan untuk menggali lebih dalam tentang kebutuhan rumah tangga yang digunakan. Jadi dalam hal ini pembelajaran informal juga dilakukan melalui masing-masing keluarga. Asumsi ini dikuatkan oleh Rogers dalam Kamil (2009:12) bahwa "Pendidikan informal adalah sebuah proses pendidikan sepanjang hayat dimana setiap individu memperoleh dan mempelajari tingkah laku, norma-norma, keterampilan, pengetahuan dari pengalaman sehari-hari dan pengaruh serta sumber-sumber pendidikan di lingkungan sekitarnya; dari keluarga, tetangga, dari lingkungan kerja dan lingkungan bermain, dari tempat belanja, dan dari perpustakaan serta media massa".

Berdasarkan hasil temuan lapang dengan teori menyebutkan bahwa proses pembelajaran informal yang terjadi dalam kegiatan sosialisasi ini pihak LPTP sengaja melakukan kegiatan pembelajaran pada masyarakat. Tetapi hal ini dilakukan di luar kegiatan pembelajaran. Proses pembelajaran yang terlihat adalah ketika masyarakat dan LPTP terlibat diskusi ketika penelusuran lapang dan sosialisasi dari rumah kerumah.

$$
\text { Menurut Yumi dan Dyah }
$$

Ediningtyas (2012:3) sekolah lapang adalah "sekolah tanpa dinding, tanpa pemisah dan pembatas, terbuka dan bersifat tidak formal dengan metode pendekatan Pendidikan Orang Dewasa (POD) guna mengembangkan dan memberdayakan petani/kelompok tani/masyarakat melalui system pembelajaran berdasarkan pengalaman dalam melaksanakan kegiatan bidang 
kehutanan". Dari asumsi diatas berdasarkan temuan penelitian, sekolah lapang yang didirikan LPTP dalam kegiatan konservasi memang lebih banyak melakukan kegiatan lapangan. Yang diajarkan LPTP terkait dengan konservasi tanah yang dilakukan.

Dalam sekolah lapang di Desa Jetis Lor ini tidak hanya menggunakan pengetahuan baru yang dibawa LPTP. Pengetahuan yang sudah dimiliki oleh masyarakat juga dijadikan bagaimana LPTP memahamkan suatu penyadaran kepada masyarakat bahwa ada yang harus dibenahi dari sistem yang sudah ada. Hal ini diperkuat oleh hakekat pemberdayaan sebagai sebuah proses, bukan instan.

Terdapat tiga tahapan pemberdayaan yaitu penyadaran, pengkapasitasan, dan pendayaan". Sekolah lapang didirikan ketika ada program konservasi tanah. Dalam sekolah lapang diajarkan berbagai pengetahuan yang terkait dengan konservasi tanah. Di sekolah lapang ada pelatihan-pelatihan yang diperuntukkan bagi masyarakat desa. Kurikulum yang diterapkan didalam sekolah lapang ini berdasarkan kesepatan bersama mengingat bahwa mayoritas pekerjaan masyarakat desa berprofesi sebagai petani. Maka dari itu kurikulum yang disusun dan waktu yang ditentukan disesuaikan dengan kebutuhan masyarkat. Asumsi ini diperkuat oleh Faisal (2006:48) pendidikan nonformal adalah "Paket pendidikannya berjangka pendek, setiap program pendidikan merupakan suatu paket yang sangat spsesifik dan biasanya lahir dari kebutuhan yang sangatdirasakan, keperluannya, persyaratan enrolmennya lebih fleksibel baik didalam halusia maupun tingkatan kemampuan, persyaratan unsur-unsur pengelolanya juga lebih fleksibel, sekuensi materi pelajaran atau latihannya relative lebih luwes, tidak berjenjang kronologis, serta perolehan dan keberartian nilai kresidensialnya tidak seberapa terstandardisir. Secara umum bisa dikatakan bahwa pendidikan nonformal relative lebih lentur dan berjangka pendek penyelenggaraannya dibanding dengan pendidikan formal".

Dalam melakukan diskusi untuk menentukan kurikulum dan segala yang berkaitan dengan sekolah lapang haruslah jelas. LPTP juga harus mengatur suasana ketika melaksanakan kegiatan sekolah lapang. Mulai dari kebutuhan yang diperlukan masyarakat terkait dengan pertanian, bahannya apa saja, merumuskan bersama tujuan belajar. Penyelenggaraan sekolah lapang mengandung proses pembelajaran nonformal. Hal ini dapat dilihat dari penyusunan kurikulum dan segala yang ada didalam sekolah lapang didiskusikan bersama antara LPTP dan masyarakat desa Jetis Lor.

Di dalam tahap penyusunan RKTD, terdapat proses pembelajaran informal. Proses pembelajaran informal ini terjadi ketika masyarakat dan LPTP melakukan penelususran ke lahan. Sebelum melakukan penyusunan RKTD masyarakat didampingi LPTP melakukan penulusuran kesetiap lahan. Di dalam penelusuran inilah terjadi interaksi dan pembelajaran didalamnya. Masyarakat yang terlibat saling berpartisipasi untuk menetukan permasalahan yang ada dilahan. Asumsi ini diperkuat oleh Faisal (2006:48-49) menyebutkan bahwa pendidikan informal adalah sebagai berikut "Pendidikan informal sama sekali tidak terorganissasi secarastruktural, tidak terdapat perjenjangan kronologis, tidak mengenal adanya kredensials, lebih merupakan hasil pengalaman belajar individual-mandiri, dan pendidikannya 
tidak terjadi didalam "medan interaksi belajar mengajar buatan" sebagaimana pendidikan formal dan nonformal...."

Berdasarkan temuan di lapangan diungkapkan bahwa sebelum melakukan penyusunan RKTD masyarakat dan LPTP melakukan penelusuran lahan. Di dalam penelusuran itu terjadi proses pembelajaran. Dimana masyarakat menjadi tahu bagaimana cara mengidentifikasi masalah dan memecahkan permasalahan itu sendiri. Setelah melakukan penelusuran ini masyarakat bersama LPTP menuliskan permasalahan-permasalahan yang ada kedalam forum. Didalam forum masyarakat berpartisipasi dalam menuangkan idenya di penyusunan RKTD.

Dari penyusunan RKTD ini yang diambil adalah termasuk dari pengalamanpengalaman masyarakat. Pengalaman yang telah dialami oleh masyarakat dijadikan pengetahuan juga. Jadi tidak semua pengetahuan yang baik dimasukkan. Jadi pengetahuan dari masyarakat tentang lahan juga dimasukkan. Asumsi ini diperkuat oleh Kamil (2009:13) "pendidikan informal memiliki kaitan yang sangat dengan 'pembelajaran pengalaman'......

Karena pendidikan informal tidak terorganisir dan merupakan pembelajaran seumur hidup, maka jelas yang dibicarakan dalam pendidikan informal adalah juga berbicara tentang pembelajaran informal". Dari asumsi di atas berdasarkan temuan lapangan, LPTP juga menggunakan pengalaman yang pernah dialami masyarakat. Pengetahuanpengetahuan yang telah mereka miliki juga digunakan dalam penyusunan RKTD.

\section{SIMPULAN}

Sosialisaasi program konservasi dilakukan melalui proses pembelajaran informal. Hal ini ditunjukkan dengan adanya sosialisasi yang tidak hanya berada di forum saja tetapi juga melakukan sosialisasi di luar forum, seperti menuju ke sungai untuk melakukan penyadaran kepada masyarakat. Hal ini juga ditunjukkan ketika LPTP melakukan sosialisasi tentang tungku. Sosialisasi tungku ini dilaksanakan selain di dalam forum resmi di balai desa, juga dilakukan dari rumah ke rumah. Sosialisasi ini bertujuan untuk mengetahui lebih jelas bagaimana kebutuhan di dalam suatu rumah tangga.

Dalam tahap sekolah lapang proses pembelajaran yang dapat dilihat yaitu proses pembelajaran nonformal. Hal ini dapat dilihat dari isi kurikulum sekolah lapang. Dalam sekolah lapang terdapat pelatihan-pelatihan yang diperuntukkan bagi masyarakat yang mengikuti sekolah lapang. Kurikulum yang ditulis pun bukan hanya ide dari LPTP tapi juga dari masyrakat. Menyesuaikan dengan kebutuhan masyarakat. Waktu yang ditentukan juga atas persetujuan masyarakat. Jadi dsekolah lapang tetap terorganisir hanya saja kurikulum yang diterapkan lebih fleksibel.

Dalam proses penyusunan RKTD proses pembelajaran yang dapat dilihat adalah proses pembelajaran informal. Hal ini dapat dilihat dari bahwa masyarakat memperoleh pengetahuan ketika mereka berada di lapangan. Memperolehnya pengetahuan ini tidak disengaja oleh masyarakat tapi disengaja oleh LPTP. Jadi LPTP menuntun ke arah agar masyarakat dapat belajar dari pengetahuan baru maupun pengetahuan yang sudah dimiliki sebelumnya. 
$R \& D$. Bandung: Alfabeta.

\section{DAFTAR RUJUKAN}

Basleman, Anisah \& Mappa, Syamsu.2011. Teori Belajar Orang Dewasa. Bandung: Rosdakarya.

Faisal, Sanapiah. 1981. Pendidikan Luar Sekolah Didalam Sistem Pendidikan dan Pembangunan Nasional. Surabaya: Usana Offset Printing.

Kamil, Mustofa. 2009. Pendidikan Nonformal. Bandung: Alfabeta.

Moedzakir, M.D. 2010. Desain dan Model Penelitian Kualitatif. Malang: Fakultas Ilmu Pendidikan Universitas Negeri Malang.

Soekanto, Soerjono. 1982. Sosiologi Suatu Pengantar. Jakarta: PT Raja Grafindo Persada.

Sugiyono. 2010. Metode Penelitian Kuantitatif dan Kualitatif dan
Supriyono. 2012. Menggagas Interkoneksi Antar Jalur Pendidikan:

Sinergi Pendidikan Sekolah Dan Pendidikan Luar Sekolah Dalam Pembangunan Pendidikan Nasional. Naskah disajikan dalam Pidato Pengukuhan Guru Besar dalam Bidang Pendidikan Luar Sekolah di Fakultas Ilmu Pendidikan Universitas Negeri Malang, Malang 10 Oktober

Yumi dan Ediningtyas, Dyah. 2012. Sekolah Lapang. Kementerian Kehutanan Badan Penyuluhan Dan Pengembangan SDM Kehutanan.

Zubaedi. 2012. Pendidikan Berbasis Masyarakat Upaya Menawarkan Solusi terhadap Berbagai Problem Sosial.Yogyakarta: PUSTAKA PELAJAR 